\title{
OVIPOSITION PREFERENCE AND LARVAL PERFORMANCE IN CERATITIS CAPITATA (DIPTERA, TEPHRITIDAE)
}

\author{
Iara Sordi Joachim-Bravo ${ }^{1}$ \\ Fernando Sérgio Zucoloto ${ }^{1}$
}

\begin{abstract}
Experiments concerning oviposition preference were carried out on Ceratitis capitata to determine whether females are able to preferentially oviposit on natural hosts in which the larvae develop better. The results indicated that the females do not preferentially oviposit on hosts of better nutritive value for the larvae. KEY WORDS. Ceratitis capitata, fruit flies, oviposition behavior, insects
\end{abstract}

Host plant selection is one of the central questions in the study of insect-plant relations. This factor is of critical importance in holometabolic insects because the larvae of these insects have relatively little mobility and depend for survival on the nutritive resources determined by adult females through their ovipositing behavior (SINGER 1986; RENWICK 1989).

A controversial point about host selection by females is if they would be able to select the host plant that would permit best immature performance. Knowledge of the relation between ovipositing preference and larval performance is crucial for the understanding of the changes in host (THOMPSON 1988; CRAIG et al. 1989). Hierarchical preferences for plant resources have been reported for various phytophagous insects (COURTNEY 1986; THOMPSON 1988) and a simple evolutionary hypothesis for explaining this hierarchy of preference is that the latter may correspond to the quality of the resources for offspring performance (RAUSHER 1979). The existence of a positive correlation between host selection for ovipositing and offspring performance has been demonstrated in some species (WHITHAM 1980; Via 1986; Price et al. 1987; DAMMAN \& FEenY 1988; AuERBACH \& SimberlofF 1989; HAMILTON \& ZALUCKI 1993; KOUKI 1993) but not in others (RAUSHER 1982; COURTNEY 1986; THOMPSON 1988; ROININEN \& TAHVANAINEN 1989; VALLADARES \& LAWTON 1991; UNDERWOOD 1994).

Studies of host selection by Ceratitis capitata have shown that adult flies use physical and chemical signals to select their hosts and may exhibit a hierarchy of preference (PROKOPY \& ROITBERG 1984; PROKOPY et al. 1985). Experiments with diet selection have shown that adults can discriminate between diets containing different proportions of carbohydrate and protein for feeding (TERAN 1978) and that they are self-selective (CANGUSSU \& ZUCOLOTO 1995). Also, larvae can discrimi-

1) Departamento de Biologia, Faculdade de Filosofia Ciências e Letras de Ribeirão Preto, Universidade de São Paulo. Avenida Bandeirantes 3900, 14040-901 Ribeirão Preto, São Paulo, Brasil. 
nate between diets that provide them with better performance, with nutritive value being the major factor for diet selection (ZuCOLOTO 1987, 1991).

The objective of the present study was to determine whether $C$. capitata females are capable of preferentially ovipositing on natural hosts or on artificial diets on which the larvae can develop better.

\section{MATERIAL AND METHODS}

Flies from a laboratory population originating from infested peaches 14 years ago was utilized, as well as wild flies obtained from coffee (Coffea arabica) fruits collected in the Ribeirão Preto region, São Paulo, Brazil.

For the experiments concerning oviposition preference and larval performance, an adequate host, papaya (Carica papaya) and an inadequate host, apple (Pyrus malus) was utilized (ZUCOLOTO 1993a).

\section{Selection of fruits for ovipositing}

The experiments concerning fruits selection for ovipositing were carried out as follows: 15 newly emerged pairs from a laboratory stock or a wild fly stock were placed in acrylic boxes $(11 \times 11 \times 3 \mathrm{~cm})$ or metal cages covered with nylon netting $(20 \times 20 \times 20 \mathrm{~cm})$, since the space can influence the results (BOLLER \& CALKINS 1984), and fed the rearing diet and water ad libitum. On the 8 th or 15 th day after emergence, when the laboratory females and wild females were at the peak of ovipositing, respectively, two different types of fruits to be tested were introduced (two pieces of each type) into the boxes or cages. The fruits were offered in pieces (5.0g). The fruit pulp was covered with aluminum foil in such a way that only the peel was exposed for ovipositing. The eggs laid on each fruit were counted 48 hours later. In the first experiment we tested oviposition preference between apple and papaya using wild flies. In the second experiment we tested oviposition preference between apple and papaya using flies reared in the laboratory. Each test was repeated 10 times and the data were analyzed by the Wilcoxon test at the $5 \%$ level of significance (SIEGEL 1956). All experiments for selection of oviposition were performed at ambient temperature of $29 \pm 1^{\circ} \mathrm{C}$ and $\mathrm{RH}$ of $75-80 \%$, with 10 hours of photophase provided by a 400 lux fluorescent bulb.

\section{Evaluation of the nutritive value of the fruits for the larvae}

The fruits tested for selection of ovipositing site on the part of females were evaluated in terms of their nutritive value for wild and laboratory larvae. Small pieces $(5.0 \mathrm{~g})$ of the fruits were placed on a Petri dish $(90 \times 16 \mathrm{~mm})$ lined with moistened filter paper. Ten newly hatched larvae were placed on the dishes. New pieces of fruits were added daily until pupation. The following parameters were employed for the analysis of nutritive value: percent emergence, time to emergence and wing size (estimated by the alar length of the left wing between the lower end of the bm-cu nervure and the end of the $\mathrm{R}_{4+5}$ nervure) calculated for 15 females per fruit previously fixed in 70\% alcohol (ZucoloTo 1987). Six replicates were performed for each experiment. Data were analyzed by the Mann-Whitney test at the 5\% level of significance (SIEGEL 1956). The experiments were carried out in the absence of light at $29 \pm 1{ }^{\circ} \mathrm{C}$ and $70-80 \% \mathrm{RH}$. 


\section{RESULTS}

Neither wild females nor laboratory-reared females showed any preference for the fruits tested (Fig. 1). Also, there was no difference in oviposition preference between the tests carried out in cages and those carried out in acrylic boxes.

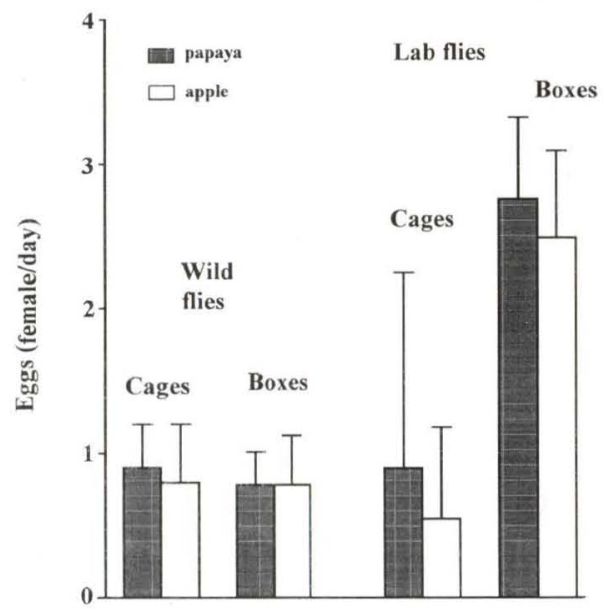

Fig. 1. Oviposition preference by wild and lab Ceratitis capitata when offered papaya and apple. The tests were carried out in cages and boxes. The results are the mean $( \pm S D)$ of ten replications. There is not statistical difference between the means $(P>0.05$, Wilcoxon test).

Concerning the nutritive value of the fruits for larvae, the results were similar for wild and laboratory-reared larvae (Tab. I). Percent emergence and life cycle differed significantly, with the better performance being obtained for larvae reared on papaya. In contrast, adult size did not differ between flies obtained from larvae reared on papaya and larvae reared on apple.

Table I. Nutritional value of papaya and apple for Ceratitis capitata larvae. The results show the means $( \pm S D)$ of six replications. Means, within columns, followed by different letters differ from one another $(P<0,05$, Mann-Whitney test).

\begin{tabular}{|c|c|c|c|c|c|c|}
\hline \multirow{2}{*}{ Fruits } & \multicolumn{2}{|c|}{ Emergence (\%) } & \multicolumn{2}{|c|}{ Time to emergence (days) } & \multicolumn{2}{|c|}{ Wing measurement $(\mathrm{mm})$} \\
\hline & Laboratory flies & Wild flies & Laboratory flies & Wild flies & Laboratory flies & Wild flies \\
\hline Papaya & $86.70 \pm 10.32 a$ & $80.00 \pm 15.50 a$ & $16.07 \pm 0,08 a$ & $15.85 \pm 0.66 a$ & $2.78 \pm 0.10 a$ & $2.98 \pm 0.12 a$ \\
\hline Apple & $15.00 \pm 8.37 b$ & $17.50 \pm 9.57 b$ & $17.00 \pm 0,00 \mathrm{~b}$ & $19.88 \pm 0.63 b$ & $2.74 \pm 0.11 a$ & $3.00 \pm 0.32 a$ \\
\hline
\end{tabular}

Parallel observations showed that most of the wild flies placed in cages survived for a longer time and started oviposition earlier (18 days) than wild flies placed in boxes (22 days).

Comparison of wild flies with laboratory-reared flies showed that wild flies started copulation approximately on the 15 th day after emergence, whereas laboratory flies usually started copulation two days after emergence. In addition, the 
oviposition period of laboratory flies started eariier, about five days after emergence, whereas the oviposition period of wild flies started late, 15 days after emergence. There was also a difference in the amount of eggs laid, which was larger for laboratory flies placed in boxes than for wild flies also placed in boxes.

\section{DISCUSSION}

Flies collected in nature usually exhibit difficulties in adapting to the laboratory, especially in relation to the new oviposition sites (LEPPLA et al. 1983; ECONOMOPOULOS 1992). Thus, the preparation of an appropriate environment is necessary for successful experiments. Wild flies kept in boxes or in cages did not show a difference in oviposition behavior, but general performance was higher in cages, suggesting that cages show better conditions for experiments of this type.

The differences between wild flies and laboratory-reared flies detected in the present study, in terms of shorter periods before copulation and before oviposition and in terms of number of eggs laid by laboratory-reared flies, agree with data reported in studies comparing wild flies and laboratory-reared flies of Tephritidae species (ROSSLER 1975; MAZOMENOS et al. 1977; WONG \& NAKAHARA 1978; SUZUKI \& KOYAMA 1980; ECONOMOPOULOS 1992). The larger amount of eggs laid by laboratory flies compared to wild flies when placed in boxes was probably due to the fact that during the larval phase wild flies had fed on coffee fruit which have a lower protein concentration than the artificial diet based on yeast used to rear laboratory flies during the larval phase.

Literatura data show that artificial fruit fly rearing in the laboratory for many generations causes deleterious changes in behavior compared to wild populations. In general, laboratory-reared populations mature more rapidly, with an increased reproductive rate and a reduced ability to fly; on the other hand, after these populations overcome the bottleneck effect, they are easily maintained although with a loss of a wild traits (KAKINOHANA 1980; LEPPLA et al. 1983); however these populations can still maintain a considerable level of genetic variability, permitting improved performance by directional selection (BOLLER \& CALKINS 1984; ZUCOLOTO 1993b).

Both in the experiments with laboratory-reared females and in the experiments with wild flies, it was observed that the females did not choose the fruit (papaya) in which the larvae would develop best. These data strongly suggest the absence of an associative relationship between ovipositing preference and larval performance.

The presence or absence of a positive correlation between ovipositing preference and larval performance has been extensively discussed. Although it seems obvious that adult females should select individual host plants or parts of a host plant where phytophagous larvae will develop better, there is no consistent evidence about this. Several factors such as the risk of predation, scarcity of the more adequate plant, presence of a favorable host plant at an unfavorable site, morphological characteristics of the plants (size and shape) not correlated with larval success, recent addition of a less favorable plant to the habitat, among other, may 
explain the lack of preference for plants of more adequate quality for the larvae (KARBAN \& COURTNEY 1987; THOMPSON 1988; NYLINN \& JANZ 1993). All of these factors probably influence to a greater or lesser extent the choice of host plants and therefore host quality seems not to be the most important determinant in the choice of ovipositing sites.

The oviposition of $C$. capitata and other Tephritidae on hosts that are inadequate for larval development is not an uncommon behavior. Several studies have shown that, under conditions of no choice, females oviposit on hosts in which the chances for larval survival are low or absent (NEILSON 1967; CAREY 1984; FLETCHER 1987; KRAINACKER et al. 1987). These results may be expected since it is known that, in general, phytophagous insects infest other plants when the appropriate hosts are not available (FITT 1986). However, in the present study, $C$. capitata females, even under conditions of choice, did not discriminate between a more adequate host (papaya) and a less adequate one (apple), demonstrating no ovipositing preference for either fruit. Although we can find positive correlation between oviposition preference and larval performance in some polyphagous insects (NYLIN \& JANZ 1993), perhaps in C. capitata, this lack of positive correlation between ovipositing preference and larval performance is mainly associated with the highly polyphagous nature of this specie. According to KRAINACKER et al. (1987), polyphagy is basically associated with the unpredictability of environmental resources, whereas monophagy and oligophagy are linked to the predictable availability of such resources. The fruits used by $C$. capitata are ephemeral and, even though their availability may be predictable on a seasonal basis, their abundance is not predictable from one season to the other (FITT 1990). Furthermore, a multivoltine species without diapause such as $C$. capitata may find several environments throughout the year, a fact that may impair selection for specialization on a certain fruit. Thus, the ovipositing behavior of $C$. capitata must have been selected for in such a way that the fly would oviposit on the largest possible number of hosts, without permitting fine discrimination between different fruits. The fact that these flies presented a low perception threshold for substances such as sucrose and citric acid (JOACHIM-BRAVO \& ZUCOLOTO 1997), both of them present in many fruits, supports this hypothesis, since only small concentrations of these substances are needed to stimulate ovipositing.

The present results also support the hypothesis of KRAINACKER et al. (1987), who stated that the expansion of insect hosts may be facilitated by a low discrimination behavior. The ability of fruit flies to expand their host gamut requires a change in ovipositing behavior favorable to the new host and larval ability to survive on the latter (FLETCHER \& PROKOPY 1991). According to FUTUYMA (1983), for phytophagous insects in general the expansion to new hosts first involves genetic changes in host selection behavior, and only later does it involve selection affecting survival in the new host. Thus, the lack of a positive correlation between ovipositing preference and larval performance of C. capitata observed here may also reflect the fly's potential for host expansion. 
ACKNOWLEDGEMENTS. We would like to thank Ana Paula dos Santos and Laércio Massocato for technical assistance.

\section{REFERENCES}

Auerbach, M. \& D. Simberloff. 1989. Oviposition site preference and larval mortality in a leaf-mining moth. Ecol. Entomol. 14: 131-140.

BOLLER, E.F. \& C.O. CALKINS. 1984. Measuring, monitoring and improving the quality of mass-reared Mediterranean fruit flies, Ceratitis capitata Wied. 3. Improvement of quality by selection. Ztschr. angew. Ent 98: 1-15.

CAngussu, J.A. \& F.S. ZuCOLOTO. 1995. Self-selection and perception threshold in adult female of Ceratitis capitata (Diptera, Tephritidae). Jour. Insect Physiol. 41 (3): 223-227.

CAREY, J.R. 1984. Host-specific demographic studies of the mediterranean fruit fly Ceratitis capitata. Ecol. Entomol. 9: 261-270.

COURTNEY, S.P. 1986. The ecology of pierid butterflies: dynamics and interactions. Adv. Ecol. Res. 15: 51-131.

Craig, T.P.; J.K. Itami \& P.W. Price. 1989. A strong relationship between oviposition preference and larval performance in a shoot-galling sawfly. Ecology 70 (6): 1691-1699.

DAmMAn, H. \& P. FeENY. 1988. Mechanisms and consequences of selective oviposition by the zebra swallowtail butterfly. Anim. Behav. 36: 563-573.

ECONOMOPOULOS, A. P. 1992. Adaptation of the mediterranean fruit fly (Diptera: Tephritidae) to artificial rearing. Jour. Econ. Ent. 85 (3): 753-758.

FITT, G.P. 1986. The influence of a shortage of hosts on the specificity of oviposition behavior in species of Dacus (Diptera, Tephritidae). Physiol. Entomol. 11: 133-143.

. 1990. Variation in ovariole number and egg size of species of Dacus (Diptera: Tephritidae) and their relation to host specialization. Ecol. Entomol. 15: 255-264.

FleTCHER, B.S. 1987. The biology of dacine fruit flies. Ann. Rev. Entomol. 32: 115-144.

FletcheR, B.S. \& R.J. ProKopy. 1991. Host location and oviposition in tephritid fruit flies, p.139-171. In: W.J. BAILEY \& J. RIDSDILL-SMITH (Eds). Reproductive Behaviour of Insects: Individuals and Populations. New York, Chapman \& Hall, 387p.

FUTUYMA, D.J. 1983. Selective factors in the evolution of host choice by phytophagous insects, p.227-224. In: S.A. AHMED (Ed.). Herbivorous Insects: Host Seeking Behaviour and Mechanisms. New York, Academic Press, 423p.

HAMILTON, J.G. \& M.P. ZALUCKI. 1993. Interactions between a specialist herbivore, Corcidosema plebejana, and its host plants Malva parviflora and cotton, Gossypium hirsutum: oviposition preference. Entomol. exp. appl. 66: 207-212. JOACHIM-BRAVO, I.A. \& F.S. ZuCOLOTO. 1997. Oviposition preference in Ceratitis capitata (Diptera, Tephritidae): Influence of rearing diet. Inheringia, Sér. Zool., 
82: 133-140.

KaKinOHANA, H. 1980. Qualitative change in the mass-reared melon fly, Dacus cucurbitae Coq. Proc. Symp. Fruit Fly Prob., Kyoto, p.27-36.

KARBAN, R. \& S. COURTNEY. 1987. Intraspecific host plant choice: lack of consequences for Streptanthus tortuosus (Cruciferae) and Euchloe hyantis (Lepidoptera: Pieridae). Oikos 48: 243-248.

KoUKI, J. 1993. Female's preference for oviposition site and larval performance in the water-lily beetle, Galerucella nymphaeae (Coleoptera: Chrysomelidae). Oecologia 93: 42-47.

KRAINACKER, D.A.; J.R. CAREY \& R.I. VARGAS. 1987. Effect of larval host on life history traits of the Mediterranean fruit fly, Ceratitis capitata. Oecologia 73: 583-590.

Leppla, N.C.; M.D. Huettel; D.R. Chambers; T.R. Ashley; D.H. MIyashita; T.T.Y. WONG \& E.J. HARRIS. 1983. Strategies for colonization and maintenance of the mediterranean fruit fly. Entomol. exp. appl. 33: 89-96.

Mazomenos, B.; J.L. NAtion; W.J. Coleman; K.C. Dennis \& R. EsPondA. 1977. Reproduction in Caribbean fruit flies: Comparisons between a laboratory strain and a wild strain. Florida Entomol. 60: 139-144.

NEILson, W.T.A. 1967. Development and mortality of the apple maggot, Rhagoletis pomonella, in crab apples. Can. Entomol. 99: 217-219.

NYLIN, S. \& N. JANZ. 1993. Oviposition preference and larval performance in Polygonia c-album (Lepidoptera:Nymphalidae): The choice between bad and worse. Ecol. Entomol. 18: 394-398.

Price, P. W.; H. RoIninen \& J. TAhVAnainen. 1987. Plant age and attack by the bud galler, Euura mucronata. Oecologia 73: 334-337.

Prokopy, R.J.; C. Kallet \& S.S. CoOlEy. 1985. Fruit acceptance pattern of Rhagoletis pomonella flies from different geographic regions. Ann. Ent. Soc. Amer. 78: 799-803.

Prokopy, R.J. \& B.D. RoITBERG. 1984. Foraging behavior of true fruit flies. Amer. Scientist 72: 39-49.

RAUSHER, M.D. 1979. Larval habitat suitability and oviposition preference in three related butterflies. Ecology 60: 503-511.

1982. Population differentiation in Euphydryas editha butterflies: larval adaptation to different host. Evolution 36 (3): 581-590.

RENWICK, J.A.A. 1989. Chemical ecology of oviposition in phytophagous insects. Experientia 45: 223-228.

RoINInEN, H. \& J. TAHVANAInEN. 1989. Host selection and larval performance of two willow-feeding sawflies. Ecology 70 (1): 129-136.

RöSSLER, Y. 1975. The ability to inseminate: a comparison between laboratory-reared and field population of the mediterranean fruit fly Ceratitis capitata (Wied.). Entomol. exp. appl. 18: 255-260.

SIEGEL, S. 1956. Nonparametric Statistics for the Behavioral Sciences. New York, MacGraw-Hill, 340p.

SINGER, M.C. 1986. The definition and measurement of oviposition preference in 
plant-feeding insects, p.65-89. In: J.R. MILLER \& T.A. MiLLER (Eds). Insectplant interactions. New York, Springer-Verlag, 527p.

SUZUKI, Y.\& J. KOYAMA. 1980. Temporal aspects of mating behavior of the melon fly, Dacus cucurbitae Coquillett (Diptera: Tephritidae): A comparison between laboratory and wild strains. Appl. Ent. Zool. 15: 215-224.

TERAN, H.R. 1978. Seleccion de alimentos por los machos e influencia de estos y del espacio vital sobre el comportamiento reproductivo de las hembras de Ceratitis capitata. Revta Agron. N. E. Argent. 15: 59-66.

THOMPSON, J.N. 1988. Evolutionary ecology of the relationship between oviposition preference and performance of offspring in phytophagous insects. Entomol. exp. appl. 47: 3-14.

UNDERWOOD, D.L.A. 1994. Intraspecific variability in host plant quality and ovipositional preferences in Eucheria socialis (Lepidoptera:Pieridae). Ecol. Entomol. 19: 245-256.

VAlladARES, G. \& J.H. LAWTON. 1991. Host-plant selection in the holly leaf-miner: Does mother know best? Jour. Animal Ecology 60: 272-240.

VIA, S. 1986. Genetic covariance between oviposition preference and larval performance in an insect herbivore. Evolution 40 (4): 778-785.

WHITHAM, T.G. 1980. The theory of habitat selection: examined and extended using Pemphigus aphids. Am. Nat. 115: 449-466.

WONG, T.T.Y. \& L.M. NAKAHARA. 1978. Sexual development and mating response of laboratory-reared and native Mediterranean fruit flies. Ann. Ent. Soc. Amer. 71: $592-596$.

ZuCOLOTO, F.S. 1987. Feeding habits of Ceratitis capitata (Diptera, Tephritidae): can larvae recognize a nutrionally effective diet? Jour. Insect Physiol. 33: 349-353.

1991. Effects of flavour and nutritional value on diet selection by Ceratitis capitata larvae (Diptera: Tephritidae). Jour. Insect Physiol. 37 (1): 21-25.

. 1993a. Acceptability of different Brazilian fruits to Ceratitis capitata (Diptera, Tephritidae) and fly performance on each species. Brazilian Jour. Med. Biol. Res. 26: 291-298.

1993b. Adaptation of a Ceratitis capitata population (Diptera, Tephritidae) to an animal protein-based diet. Entomol. exp. appl. 67: 119-127.

Recebido em 17.X.1996; aceito em 18.IX.1997. 